\section{Commerce, conflict, and contamination: yellow fever in early- independence Veracruz in the US imaginary, 1821-1848}

\section{Comércio, conflito e} contaminação: imaginário estadunidense sobre a febre amarela na recémindependente Veracruz

Beau D.J. Gaitors

Assistant Professor, History, Politics, and Social Justice/ Winston-Salem State University.

Winston-Salem - North Carolina - USA

bgaitors@gmail.com

Received on 13 Jan. 2017.

Approved on 2 Jan. 2018.
GAITORS, Beau D.J. Commerce, conflict, and contamination: yellow fever in early-independence Veracruz in the US imaginary, 1821-1848. História, Ciências, Saúde - Manguinhos, Rio de Janeiro, v.25, n.3, jul.-set. 2018, p.779-795.

Abstract

While commercial links between Mexico and the United States through the port city of Veracruz brought significant economic and social advantages in the early nineteenth century, public health concerns around yellow fever produced fascination and fear among US audiences (in southern and eastern port cities) from times of peace until the US invasion and occupation of Mexico (1846-1848). This article addresses the complex linkages between commerce, conflict, and contamination in reference to the port city of Veracruz and the United States in Mexico's early decades of independence. More specifically, this article addresses the concern in early nineteenth-century US periodicals around yellow fever outbreaks and potential contamination, showing the constant presence of yellow fever in Veracruz in the US imaginary.

Keywords: commerce; disease; Veracruz; yellow fever.

\section{Resumo}

Enquanto os vínculos comerciais entre México e EUA por meio da cidade portuária de Veracruz trouxe vantagens econômicas e sociais significativas no início do século XIX, preocupações em torno da febre amarela produziram medo e fascínio entre o público estadunidense (em cidades portuárias do sul e do leste) desde os tempos de paz até a invasão e ocupação estadunidense do México (1846-1848). O artigo aborda os complexos vínculos entre comércio, conflito e contaminação relacionados à cidade portuária de Veracruz e aos EUA nas primeiras décadas da independência do México. Especificamente, trata a preocupação com surtos de febre amarela e a potencial contaminação encontrada em periódicos estadunidenses no início do século $X I X$, mostrando a presença constante da febre amarela em Veracruz no imaginário estadunidense.

Palavras-chave: comércio; doença; Veracruz; febre amarela 
$I^{n}$ $\mathrm{n}$ the Gulf of Mexico lies one of Mexico's most important port cities, Villa Rica de la Vera Cruz. Veracruz serves several purposes for Mexico. It is a central tourist destination, especially during the Carnival season, as thousands of people come from the interior of Mexico and from abroad to this port city to enjoy the week-long festivities in Veracruz. Beyond the tourism and social activities, Veracruz serves as Mexico's main naval base in the Gulf of Mexico. One of the most important contributions that Veracruz provides is as a central trading depot for Mexico, a position that it has occupied since colonial times. Throughout its history, Veracruz has been a bustling city with commercial activity from dawn until dusk. Authors of travel narratives from the colonial and early independence eras often wrote about the lively scenes in the port as dockworkers unloaded ships arriving from the farthest reaches of the Atlantic world and the close ports of the Gulf of Mexico, making the city integral to Mexican commercial endeavors (Delgado, 1992).

Despite its commercial centrality, fears of the outbreak of various diseases produced an image of the city as a metropolis of pestilence. The tropical climate that made the region agriculturally productive and the city a lucrative locale also led elites to view the port as unsanitary and physically unattractive for settlement, due to its susceptibility to diseases such as yellow fever and malaria (García Díaz, 1994; Ochoa Contreras, Velásquez Ortíz, 1986; Siemens, 1990; Southworth, 1900). In the Atlantic world in the nineteenth century, the theories of miasmas and contagion dominated notions around the spread of diseases like yellow fever. The theory of miasmas "held that the cause of illnesses and epidemics was bad environmental conditions. These conditions ranged from temperature to unhealthy living conditions" (Lodola, Gois Junior, 2015, p.2). Individuals focused on contagion argued that "diseases spread through contact with a sick person" (p.2). The aforementioned period predates scientific advances in research on the spread of yellow fever in the late nineteenth and early twentieth centuries; as such, researchers from the time of this study did not know of the transmission of yellow fever to humans by the bites of the Aedes aegypti mosquito. Indeed, when viewing the spread of yellow fever, one sees that both the supporters of contagion and those of miasmas held some accuracy during their time. The disease spread from unhealthy hosts to healthy individuals and the climate and environmental conditions had to be just right for the living conditions of the $A$. aegypti mosquito to persist. More specifically, during the rainy season the health hazards related to yellow fever increased dramatically because mosquito larvae were able to grow in large pools of standing water throughout the city. Indeed, government officials' poor handling of public hygiene and sanitation, combined with the region's climatic conditions, positioned Veracruz as a perfect incubator for yellow fever. Beyond the actual outbreaks of disease, many travelers noted the irony that the two hospitals in the city served more as potential health hazards than places of refuge and recovery (Archer, 1971, p.430). The contagious people in the hospital served as hosts for yellow fever, and the mosquitoes living in standing water near and within the hospitals could easily infect large numbers of people hospitalized for other health-related issues. Increased health concerns based on rumor and reality in Veracruz reinforced the notions of this city as a metropolis of pestilence.

Due to the constant perceived and real outbreaks of disease in the port, elites and other travelers often sought the "healthier climates" of Mexico upon docking at the shores of 
Veracruz. More specifically, during the rainy season travelers noted in their journals the haste with which they left the port city (Delgado, 1992). These individuals tended to settle in alleged healthier areas around Xalapa, Puebla, or Mexico City, comfortably situated in the high altitudes of the mountains (Chico, 2006; Juárez Martínez, 1995, p.22-24). While the cases of yellow fever drastically reduced in these mountainous regions, these travelers did not understand the correlations between the environment they chose and reduction in outbreaks: the vector of yellow fever, the $A$. aegypti mosquito, has a reduced rate of existence in spaces with a combination of high altitudes and low temperatures (Lozano-Fuentes et al., 2012).

While other diseases certainly impacted the daily lives of individuals, many people feared yellow fever because of its disastrous impact, reducing populations rapidly. In the United States, concern over yellow fever in the early nineteenth century did not simply address foreign countries. In fact, at the end of the eighteenth century, one outbreak of yellow fever brought fear to the US population and impacted the masses as well as politicians. That particular outbreak took place in 1793 in Philadelphia and caused great concern as thousands of inhabitants died as a result of the disease and others fled the city. Given that many in Philadelphia (and in other US cities) thought that the disease came as a result of those fleeing Haiti during the Haitian Revolution, a continued concern a few decades later potentially rested on outsiders (and their ships) carrying the disease from tropical climates to the port cities of the United States. Both goods and the constant flow of people from Veracruz meant that yellow fever could possibly arrive on the shores of US port cities with the travelers who ventured between these cities.

Veracruz did not simply serve as a harbor for disease or a way station for passersby. At the dawn of Mexican independence, Veracruz existed as an international trade link to the Gulf of Mexico, and its inhabitants conducted commerce with traders in cities such as Havana and New Orleans and participated in the broader Caribbean and Atlantic trade networks with traders in cities such as Caracas and Cartagena, as well as the European nations of England, France, and Spain (Álvarez, 2008; Bullock, 1971; BNCE, 1965; Lucena Salmoral, 1983). As such, Veracruz remained of vital economic importance for Mexico and other nations, as dockworkers continued to unload and replenish ship cargos in the city's harbors despite the potential for yellow fever outbreaks. While outbreaks of yellow fever in Veracruz existed before the independence of Mexico, the United States imagined yellow fever in Veracruz in the early decades of Mexican independence in close connection with the well-being of US southern and eastern port cities in concerns of economics and health. Periodicals in eastern and southern port cities in the United States constantly depicted this relationship and discussed the role of yellow fever in Veracruz in US-Mexican trade relations and during the Mexican-American War (1846-1848).

This article explores the role of yellow fever in early nineteenth-century Veracruz in the US imaginary through a careful analysis of periodicals from southern and eastern US port cities that had strong trade relationships with Veracruz. More specifically, this article addresses the ways that periodicals in specific US port cities detailed yellow fever in Veracruz in relation to the United States in terms of commerce, conflict, and contamination. To be clear, the periodicals employed in this article were not the only US newspapers 
representative of the medical, political, and commercial concerns that yellow fever in Veracruz brought to the US imaginary. However, the periodicals employed have a strategic significance as they represented some of the US cities that had the highest volumes of trade with Veracruz in the early nineteenth century. As such, the periodicals employed in this paper provide a lens to view the connections that linked Veracruz and the United States through commerce and conflict, with yellow fever as a constant thread. This work is divided into two sections that engage the role of yellow fever in the early decades of independence in Veracruz. The first section particularly addresses commercial relations created in the early independence period and the link between trade and disease. Periodicals from port cities in the eastern and southern United States constantly looked to outbreaks of yellow fever in Veracruz with anxiety about the potential for the spread of yellow fever to US port cities that conducted trade with Mexico's primary port in the Gulf of Mexico. The second section focuses on the Mexican-American War and details the crucial role that yellow fever in Veracruz played in US military strategy prior to the invasion of Mexico through the port of Veracruz. Furthermore, the second section details the consequences of yellow fever in both the fears and infections that US troops experienced when they passed through or remained in the port city. In peaceful times of commerce and in conflict, yellow fever in Veracruz remained ever-present in the American narrative as a constant threat to the health of those venturing to the port city and those living in the United States in the early decades of Mexican independence, as seen through an analysis of US periodicals.

Given the role of some US port cities as initial points of contact for goods and people coming from ships arriving from Veracruz, these cities often served as buffers for the rest of the United States at this time in its relations to and reception of Veracruz. I refrain from stating that these cities operated as the sole US connections to Mexico given the fluid contact along the US-Mexico border during this period. Thus, these cities played a unique role in US-Mexico contact but did not by any means represent the totality of trade relationships. Also, other port cities, such as Tamualipas in the state of Tampico and various cities in the Yucatan, had constant communication and commerce with port cities in the United States. Yet the cities employed in this article had a unique interest in specifically reporting outbreaks in Veracruz because of their direct connection with Veracruz. As a result, they helped to influence US imaginary around yellow fever as the first to report outbreaks and they demonstrated the concerns of doctors in the interior of the United States, as well as populations living along the Atlantic and Gulf littoral.

\section{Early independence and commerce}

In the late colonial period, the port city of Veracruz had a reputation as a hotbed for tropical disease outbreaks that created concern and fear for foreigners and inhabitants. Between the years 1789 and 1794, the Second Count of Revillagigedo, Juan Vicente de Güemes Horcasitas y Aguayo, served as the Viceroy of New Spain. During his voyage from Spain to the colonial capital of New Spain, Mexico City, he traveled through the port of Veracruz, given its role as the principal port for New Spain and his role as viceroy. In the city of Veracruz, the viceroy immediately witnessed what travelers to Veracruz had written 
about for centuries: constant commercial activities and the intermittent outbreaks of disease in the port. According to Carmen Blázquez Dominguez (2000, p.22), late-colonial health concerns led foreigners to characterize Veracruz as an uninhabitable city due to the excessive heat and an abundance of mosquitoes. Along these lines, the viceroy found the climate of Veracruz dangerous to his health and departed to the interior of the region earlier than he initially planned. However, prior to leaving, the viceroy deemed the hospitals in Veracruz, San Carlos, and San Juan de Montesclaros as potential health hazards to the entire population (Archer, 1971, p.430). In response to the conditions that he witnessed, Revillagegido implemented sanitation policies for the port. Revillagegido's projects included programs to sweep the streets and rid the port of standing water, which improved health conditions of individuals living in the city. Such improved conditions had the potential to entice visitors to remain in the city for longer and even led some people to settle in Mexico. Despite the aforementioned late-colonial endeavors, outbreaks of tropical diseases such as yellow fever continued to take place in Veracruz well into the independence period.

The outbreaks of disease that took place in Veracruz made it different from most cities in the interior of Mexico, especially those mountainous regions that did not suffer the constant reemergence of yellow fever. Yet this distinguishing characteristic linked Veracruz to other humid areas in Mexico, such as the Yucatán. For audiences in the United States, commerce and conflict with Mexico brought about severe public health concerns in the early nineteenth century, especially in relation to Veracruz. The location of Veracruz within the lowland tropics made it a center for disease development. This location meant that it had a hospitable climate for yellow fever, which persisted as people migrated to and through the port city. Throughout the nineteenth century, researchers like the French medical practitioner Denis Jourdanet engaged varying theories around the cause and cure of diseases like yellow fever. Jourdanet looked to the impact of the climate on disease, and his mid-nineteenth-century research focused on the ways that altitude helped to reduce the impact of pulmonary diseases (Auvinet, Bruilet, 2004). Jourdanet observed and commented on yellow fever outbreaks in the Gulf Coast of Mexico as he landed in Veracruz in 1842 (Auvinet, Briulet, 2004).

A review of the Mexican historiography on yellow fever provides ample opportunities to see the significance of yellow fever in Veracruz. Authors in the nineteenth century such as Juan Luis Chabert, Casimiro Liceaga, and J.B. Saunier engaged the various concerns around the disease and wide range of methods to cure the infected that had gained prominence by the nineteenth century, which included the use of quinine, mercury dosages, and the huaca plant among other methods (Chabert, Liceaga, 1828; Saunier, 1866). Towards the end of the nineteenth century, researchers of yellow fever in Veracruz conducted more centralized research projects at the civilian hospital and authors in Mexico took note and published their findings for the broader engagement of a wider audience (Alvarado, 1897; Pedrera, 1883). Authors from the twentieth and twenty-first centuries discussed yellow fever with the advantage of knowing the role that mosquitoes played in transferring the disease, of which those in the nineteenth century did not have concrete knowledge, and provided a retrospective lens to the cause and cures of yellow fever in Veracruz during the nineteenth century (Cuenya, Estrada Urroz, 2013; Varela, 1952; Viesca Treviño, 2010). 
Several works that discuss yellow fever in Veracruz tend to focus on the twentieth century and engage the important successes of the Rockefeller International Health Campaign and local governmental efforts to eradicate the cause and spread of yellow fever in Veracruz (Birn, 2006; Wood, 2001). Yet these works tend to overlook the position of yellow fever in Veracruz in the nineteenth century, during the time of confusion and misunderstandings that led to experimentation, distancing, and struggles of those who lived in or passed through Veracruz. For example, in the late nineteenth century, authors and researchers such as S.T. Trowbridge and George Miller Stern began to publish on their research endeavors around outbreaks and experiments related to yellow fever in Veracruz (Rio, 1892; Roseneau et al., 1905; Sternberg, United States, Marine Hospital Service, 1890; Trowbridge, 1883). These experiments happened on the ground and diverse audiences read about them, making nineteenth-century Veracruz a focal point in the United States in terms of yellow fever research and developments.

Early nineteenth-century periodicals would constantly depict the ravages of yellow fever in the port city of Veracruz. Newspapers from Boston, New Orleans, Charleston, and New York would report commercial news as well as outbreaks of disease that took place in Veracruz. The primary purpose of these newspapers served to provide readers with a sense of events taking place more broadly throughout the Atlantic world, yet the position of Veracruz and yellow fever seeped through the pages of these periodicals, warning would-be travelers and foreign observers of the potential health hazards that Veracruz held.

After weeks on ships, traveling across the Atlantic Ocean and subsequently through the Gulf of Mexico, travelers arrived to newly independent Mexico at the hot and humid shores of Veracruz. Upon arriving to the port of Veracruz, many travelers confirmed their preconceived notions, as the porousness of the city made it an incubator and host for the mobility of microbes that infected visitors. Many referred to outbreaks and the environment of Veracruz in their diaries, due to the overbearing humidity and the constant outbreaks of yellow fever that Mexicans from the interior and foreigners alike suffered (Delgado, 1992). They also encountered another staple in the port, street vendors, who made this undesirable environmental space a commercially rich one. They would have witnessed a populated port full of constant commerce. At times the port, as today, dealt with strong wind currents known as nortes that slightly disrupted daily life, as the sands from the surrounding shores whisked into the city streets. They would have also been attacked by the abundance of mosquitoes in the port, which thrived because of the numerous pools of standing water throughout the city.

By the 1820s, US periodicals produced a range of depictions of the port city of Veracruz in relation to its cleanliness. As one contributor to the Boston Commercial Gazette (23 jan. 1823, p.1) wrote in January 1823, "The city of Veracruz is represented as one of the prettiest foreign towns which the writer has seen: for symmetry and cleanliness it will vie with Philadelphia." Furthermore, in 1824, US physician and first Minister to Mexico Joel Roberts Poinsett stated that Veracruz "is compactly and very well built, and so extremely neat and clean that from an examination of the interior of Veracruz, it would be difficult to account for the causes of the pestilential diseases for which it is unfortunately celebrated". 
Poinsett's observation fit within a dominant narrative in which observers from the United States of America regularly depicted fears of the spread of disease, such as yellow fever, from Veracruz in the early nineteenth century. Indeed, early nineteenth-century US periodical editors published stories about the movement of goods and disease from Veracruz in the sections related to disease and commerce, demonstrating the knowledge of the centrality of Veracruz as a space where commercial endeavors took place, as well as where notions of transmittable diseases emerged.

Mexican periodicals from the early nineteenth century attest to the commercial position that Veracruz held, given the constant entrance of ships with goods assigned to specific merchants. With the achievement of independence, Mexico became more integrated in the larger Atlantic world commercial system and expanded on the connections previously established in colonial times. As one of Mexico's chief port cities on the eastern coast, Veracruz played a central role in the exportation of Mexican products. Merchants employed ships to connect Atlantic world ports, using Veracruz as the corridor to supply the demand for cochineal, coffee, vanilla, and other items to cities of the Atlantic littoral (Garcia Sancho, 15 May 1845). Ships containing the aforementioned items left Veracruz and ventured to Havana and New Orleans in the Gulf of Mexico, traveled to Tabasco and Campeche to connect Veracruz to southern ports of Mexico, and crossed the Atlantic Ocean to such ports as Cadiz, Bordeaux, and London, increasing the income of merchants in Veracruz (El Censor, 31 July 1839, p.4; Customs income, n.d.). These connections placed Veracruz as a central node in Mexico's international political and commercial relationships during the first decades of Mexican independence (Codinach, 1988; García Díaz, Guerra, 2002; Lucena Salmoral, 1983). Merchants' connections abroad rested heavily on the transmission of material goods from the Atlantic world to the port of Veracruz, which dockworkers facilitated as they welcomed people and goods into the nation. Products on ships from Veracruz arrived to the ports of New Orleans, Charleston, New York, Philadelphia, and Boston, where vendors sold goods in the port and subsequently distributed these goods to the rest of the American population, where people consumed, adopted, and adapted various Mexican products throughout the United States.

While commerce with Mexico continuously occupied space in newspapers in the United States, there was also constant news regarding disease, particularly the outbreaks of yellow fever that took place in Veracruz. Given the consistent trade, the Gulf region was known as a space for the fluid movement of disease, goods, and people alike (Ronzon, 1998). From the first entrance of the US ambassador to Mexico, Joel Roberts Poinsett, the position of yellow fever in Veracruz received significant attention in US periodicals. A letter from the Charleston Courier, quoted in the Boston Commercial Gazette, immediately engaged the question of yellow fever. As a result of a yellow fever outbreak in January 1823, "the city of Veracruz [was] represented to be in a dreadful situation" (Boston..., 30 Oct. 1827, p.1). According to the periodical, the yellow fever outbreak brought business to a standstill and reduced adventurers of all nations to poverty. News of this particular outbreak traveled up the eastern coast of the United States as the Rhode Island American and General Advertiser newspaper reported the same situation as the Boston Commercial Gazette (Rhode-Island American..., 28 Jan. 1823, p.2). 
By February 1823, discussions of quarantines in relation to ships coming from Veracruz emerged in periodicals and fit directly into the dominant nineteenth-century theories about the spread of yellow fever as miasma or contagion. US editors from the Evening Post (New York) referenced extracts of American author Peter S. Townsend's work Townsend on Veracruz, which addressed yellow fever concerns in relation to quarantine in 1822. More specifically, the work detailed the conflicting nature of perceptions of the permeability of the disease in reference to New York. The Evening Post's discussion of quarantine fit into some of the dominant theories attempted to reduce the spread of yellow fever in the late eighteenth and early nineteenth centuries in relation to Mexico (Alcalá Ferráez, 2010; Maroño, 2015). Some authors in the United States had skeptical reviews of the value and true validity of efforts at quarantining ships coming from Veracruz, attesting to the notion of uncertainty related to the reduction of the spread of yellow fever in the early nineteenth century (Evening Post, 21 Feb. 1823, p.2). On the one hand, those believing that the environment impacted disease looked internally to their city's sanitation. As such, a quarantine of a ship would not reduce the numbers of outbreaks in the city. On the other hand, many researchers and individuals were convinced of the spread of disease as contagion and believed that officials needed to restrict contact of potentially infected travelers coming from the West Indies and other port cities seen to have high concentrations of infected persons. As such, for these individuals, quarantine would be the best option to reduce the spread of disease. The Evening Post reprinted Townsend's section titled the "Proof of the inefficiency of quarantining," which listed vessels that arrived to New York during the summer and autumn of 1822, "from West Indies ports where Yellow Fever usually prevails" (Evening Post, 21 Feb. 1823, p.3). Veracruz was listed among the top five places of vessels to New York that reported yellow fever among the passengers. Below are Townsend's findings:

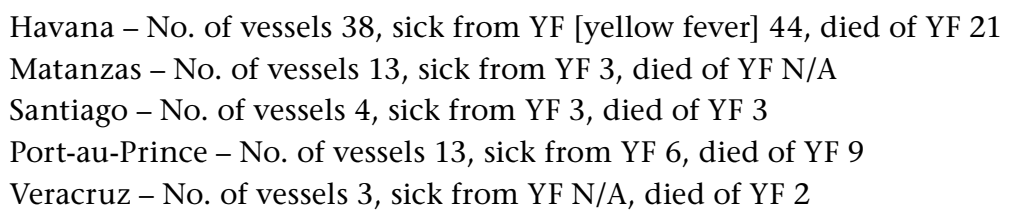

By June 1826, discussions of yellow fever in Veracruz had been detailed in depth in US periodicals. The periodical Rhode-Island Republican (29 June 1826, p.2) published about an outbreak of yellow fever in the port of Veracruz. The details would have shocked readers on the East Coast and the South of the United States. In fact, the report from the Rhode-Island Republican was a reprint from the Mobile Commercial Register of Alabama after a ship arrived in Veracruz on May 16. At that time, "the Yellow Fever was raging with great violence; and that the deaths had for some time averaged about 100 a day" (Rhode-Island Republican, 29 June 1826, p.2). The article not only detailed the number of deaths but also the rapid manner in which the disease attacked its victims and the probability that most infected individuals would not survive more than 14 hours. Periodicals also stated that the devastation of yellow fever in Veracruz was indiscriminate and it killed Mexican soldiers and Americans alike. The soldiers who 
contracted the disease most often came from the interior of the country to serve their rotational post in the port, where they were susceptible to contracting the disease. The Rhode-Island Republican (29 June 1826, p.2) stated, "The officers of the Mexican men of war in port had nearly left the service in disgust, and about one hundred and fifty seamen had sailed for the United States."

Not only did the periodicals express the devastation of yellow fever in the port; periodicals also became a way for people to understand how yellow fever impacted those who contracted the disease, how officials dealt with it in Veracruz, and the implications for citizens in the United States. In Savannah, Georgia, the Daily Georgian expressed how "small red spots of irregular shape appear on the face and body. It attacks the patient in different ways. In Vera Cruz, it generally commences with pain in the head and back, with weakness and nausea and sometimes vomiting, with desultory pains in the limbs the febrile symptoms continue generally 24 hours when it gives way, but in many cases returns at irregular periods" (Daily Georgian, 5 Aug. 1828, p.2). Veracruz was not only a space where yellow fever attacked inhabitants and visitors; Veracruz also held potential cures for victims of the disease. The periodical states that in May 1827, a patient took a specific remedy to reduce the impact of the disease. In this case, the cure was "an ounce of Epsom salts with one grain of tartar emetic, and rice or barley water as a drink" (Daily Georgian, 5 Aug. 1828, p.2). Despite the attempted use of cures for the disease, the extent of the contagion caused fears of a rapid spread to the United States. As one contributor to the Daily Georgian (5 Aug. 1828, p.2) stated, "It will doubtless go through the United States for it is as contagious as small pox or measles, and may excite some alarm at this season of the year till we become acquainted with it." This same notice came through to Massachusetts in August 1828 in the Massachusetts Spy (6 Aug. 1828, p.1).

Despite the outbreaks that ravaged Veracruz and filled the pages of US periodicals, trade between Veracruz and US port cities continued. In Baltimore, the Baltimore Gazette and Daily Advertiser gave extensive details of goods on a schooner from Veracruz that carried (among other items) cochineal, burlaps, cotton, and silk (Baltimore..., 10 Feb. 1830, p.1). By 1833, newspapers throughout the southern and eastern coasts of the United States continued to place Veracruz in either the trade or disease sections, demonstrating the dual perspective of commerce and contamination that encapsulated Veracruz. Discussions of epidemics in Veracruz highlighted fears of Atlantic spread of disease. This growing media concern over Veracruz and other Caribbean ports centered on the evolving relationship between the trade in goods, microbes, and knowledge. Indeed, yellow fever outbreaks in ports like Veracruz had repercussion for all port cities on the southern and eastern littoral of the United States.

In June 1833, US concern over yellow fever continued and officials responded with various attempts to restrict the spread of yellow fever to the rest of the population. Perhaps this escalated concern emerged as a result of the 1832-1833 global cholera outbreak that decimated populations. That outbreak created heightened concern about the transmission of disease across borders and waterways and the need to find ways to reduce disease transmission. In the summer of 1833, Veracruz had suffered a deadly yellow fever outbreak that reduced the population and became a concern for US periodicals in 
port cities. Correspondence from June 1833, later published in Newport, Rhode-Island's Newport Mercury (13 July 1833, p.2), explained, "One letter states, that an eighth part of the population had fallen." Officials took a wide range of measures to restrict and reduce the spread of the disease. Despite Townsend's report a decade earlier on the difficulties of restricting the flow of disease, in the Evening Post of New York, US port cities began to quarantine trade ships coming from Mexican ports. Officials in Veracruz took steps to improve sanitation in the city, reinstating late-colonial policies of routinely cleaning the streets. At the same time that government officials sought to reduce the outbreak of diseases, city officials also tried to cure those already infected. A list of remedies had been tried to varying degrees of success throughout the city, which led officials to search for trained medical practitioners to deal with yellow fever. Officials in Mexico City sent two doctors to Veracruz to cure those infected in the city. Yet the most effective doctor, according to the Veracruz periodical El Censor, Chavert, a native of New Orleans living in Veracruz. Veracruzanos saw Chavert as a savior due to his application of the plant huaca to those infected. Contributors to periodicals praised Chavert's cure, because it was easily made and safe for those who used it (El Censor, 29 Aug. 1833). By the end of 1833, through natural causes and possibly aided by the city's attempt to rid the streets of stagnant water, Veracruz survived this most recent threat to the health of the port.

Given the extent of outbreaks and the failure of some cures, several newspapers remarked on the reduction in population in Veracruz in the early 1840s. In New York, the Evening Post (15 May 1841, p.2) stated that some cases of yellow fever had been reported by the authorities of Veracruz in April 1841. The Sun (28 May 1842, p.1) of Baltimore reported to its readers that the outbreak continued into 1842. The contributor discussed the way that the vomito, or yellow fever, was raging with considerable violence. Yet, as earlier witnesses to the ebbs and flows of outbreaks in Veracruz expressed, the contributor stated that yellow fever was "somewhat abated in consequence of the prevalence of northerly winds" (Sun, 28 May 1842, p.1). In South Carolina, news came to the Southern Patriot (8 May 1842, p.2) that the US Frigate Macedonia had arrived in Veracruz and witnessed a yellow fever outbreak that resulted in thirdy to forty deaths per day. The outbreak continued into 1843, and on June 3, the Spectator (3 June 1843, p.3) of New York reported six hundred sick, with several deaths occurring daily. Two weeks later, on June 17, the Albany Evening Journal (17 June 1843, p.2) and the Philadelphia Inquirer (17 June 1843, p.2) reported a statement from the New Orleans periodical N.O. Bulletin and Bee that the sick had increased to eight hundred, consisting principally of Mexican soldiers from the interior of Mexico, who died rapidly.

It was not simply the reporting of the devastation of yellow fever in Veracruz that entered the US imaginary. Many people from the United States died in Veracruz, and periodicals reported these deaths in their records. For example, in December 1843, the Commercial Advertiser (27 Dec. 1843, p.2) of New York reported that Mr. Robert Honeywell of New York had died of yellow fever in November as a result of time that he spent in Veracruz. Although newspaper contributors discussed deaths as a result of the outbreaks of disease, it is more plausible that a combination of death and fluctuating migration patterns led to the vast reduction of the population in the port. Low residential numbers during outbreaks may 
have also been more of a reflection of the reduced transient population residing in the city and travelers rapidly moving outside of the city to healthier climates. Furthermore, the population may have also remained low because fears about migrating to the port kept the numbers low, especially during times of disease outbreaks.

\section{Conflict and contamination: yellow fever and the Mexican-American War}

During the final stages of independence struggles against Spain, the port of Veracruz was an epicenter of battle, a central location where new and old powers were both implemented and contested. Only a decade after Spanish troops left, Veracruz was again the center of conflict, as French troops invaded the port to recover Mexican debts incurred during the struggles for independence. This led to a war between France and Mexico known as the Pastry War. In November 1838, a French expedition of 26 ships appeared off the coast of Veracruz and blockaded the port for six months, causing an economic downturn and seriously impacting the lives of the inhabitants of the port, who depended on commerce for survival. Despite the negative impact of the blockade, the inhabitants of Veracruz neither surrendered nor consented to the French.

Veracruz remained free of invasions for nearly a decade, until the Mexican-American War with the United States began in 1846, once again making Veracruz the center of struggle. As the devastation of disease reduced in the mid-1840s, the tragedy of international conflict once again presented itself in Mexico, which would only be impeded, once again, by Atlantic world forces, in the form of the US invasion during the Mexican-American war in 1846. The possibilities created with the coming of independence simultaneously enhanced stronger international commerce and placed Veracruz as a hotbed of violence during times of international conflict. This circumstance forced inhabitants of Veracruz to face the murky nature of uncertainty and insecurity that independence brought through commercial expansion and military conflicts that emerged in the early decades of independence. Furthermore, Mexican troops often refused to take station in Veracruz because of its history of disease, leaving the port particularly vulnerable to initial attacks (Cruz Velázquez, 1998; Knaut, 1997). While in reference to trade, yellow fever in Veracruz was a constant issue in the US imaginary, yellow fever also seeped into the US media during times of conflict.

In May 1846, the US navy blockaded Veracruz, yet the issue of yellow fever immediately became a factor in strategic military action. The United States sent seventy ships to the port city and US troops stationed themselves in the Gulf of Mexico, a few miles from the shores of the port, in preparation for an invasion of Veracruz (Foos, 2002, p.84). Yet the potential for yellow fever outbreaks limited the timeframe for a successful invasion. As the Tri-weekly Ohio Statesman (27 July 1846, p.2) mentioned, "nothing will happen, until after the black vomit, or yellow fever, which now prevails in Veracruz, subsides: this may be expected about the first of October." According to an August 1846 report from the Newburyport Herald (7 Aug. 1846, p.2) and the Massachusetts Spy (12 Aug. 1846, p.1), US troops stationed themselves under Green Island (Isla Verde), a few miles from the docks of Veracruz. Both periodicals reported that yellow fever caused great havoc among Mexican 
troops on the island and in the city. As Andrew Mcllwaine Bell (2010, p.3-4) makes clear in his work, Mosquito soldiers, in reference to the Civil War in the United States, diseases like yellow fever and malaria often operated as "a mercenary force, a third army, one that could work for or against either side depending on the circumstances." Bell's statement held true for Mexican troops during the Mexican-American war as "The [Mexican] soldiers being mostly from the interior are not accustomed to the climate, and therefore suffer in health very severely" (Newburyport Herald, 7 Aug. 1846, p.2; Massachusetts Spy, 12 Aug. 1846, p.1).

In Jack Bauer's travel narrative of the Veracruz expedition of 1847, he made clear the fear of yellow fever that the invading US navy had (Bauer, 1856). More specifically, American military soldiers and officials knew that the yellow fever season would start in April or early May during the invasion of 1847. Bauer stated that in February, the US military landed on the shores and seized Veracruz, and General Scott immediately moved inland before the disease season in late April. Clearly, the US forces saw the potential for disease contraction in Veracruz as a significant barrier to their mission of conquest. In this regard, Bauer noted how General Scott strategized against the Mexican military and microbial forces to ensure victory. In April 1847, the Daily Union (7 Apr. 1847, p.4) of Washington DC and the Easton Star (13 Apr. 1847, p.2) of Maryland reported that a Mexican bearer of dispatches was caught and detained. One dispatch stated, "Veracruz to the honest men in the enemy's camp ... you can expect no other result of your imprudent enterprise than to perish under the severe influence of the climate. Yellow Fever which has already begun, one after one will carry away all of you very soon without a comfort having for a grave."

After taking over the port, the new Governor of Veracruz, General William J. Worth, adopted plans to address the outbreaks, engaging in theories related to the cause and spread of disease. The General instructed a large labor force of Mexicans to tear down the barricades and open the walls of the city in order to allow fresh air to flow into the city, in an attempt to rid the city of the miasmas thought to cause the spread of yellow fever. Although many periodicals reported yellow fever cases at this time, Governor Worth decided to wait before giving the disease any credit for the deaths, according to the Augusta Chronicle (16 Apr. 1847, p.2) of Georgia. However, readers of the Evening Post (29 Apr. 1847, p.2) in New York would learn that more than two thousand soldiers were sick with yellow fever and dysentery, probably symptoms of cholera, after 15 days. The periodical reported that soldiers stated they desperately needed to travel inland to escape their plight. According to a report in the Milwaukee Sentinel, first published in the New Orleans Picayune, the sickness had reached such a critical point that the War Department engaged a large number of physicians from New Orleans to travel to Veracruz and remain in the city during the yellow fever season. According to a report in the Milwaukee Sentinel (14 May 1847, p.3), the health of the troops steadily improved and yellow fever was no longer present in the port.

By June 1847, individuals from the United States were being enticed to travel to Veracruz, and the only issue restricting them was the potential of contracting yellow fever, which had been reduced after the invasion. The Augusta Chronicle (7 June 1847, p.2) reprinted a story from the New Orleans Picayune that gave promising details of the city for those who wanted to visit. The author attempted to alleviate fears of yellow fever in the narrative, 
stating that, "I passed through (the hospitals) thinking I should see some cases of vomito." However, according to the periodical, the head of the medical department stated that only three or four cases of yellow fever existed and that, although individuals attempted to induce Americans to leave Veracruz, it was a healthy city. According to the author, "Vera Cruz, with its neatly paved streets, its well-regulated police, its invigorating sea breezes, must be, and is, as healthy as almost any port south of the Chesapeake" (Augusta Chronicle, 7 June 1847, p.2). By June 28, 1847, editors from the Baltimore periodical, the Sun (28 June 1847, p.1), reported a circular from General Scott's Army. The circular stated that in yellow fever cases, an average of nine or ten people died per day, yet it was "confined to laborers and foreigners (not Americans). We make this statement on undoubted authority." This assessment meant that the disease would not harm Americans venturing to Veracruz (a clear reference to perceived American exceptionalism), which increased the potential to entice travelers. The New York Herald (12 July 1847, p.1) reported a drastic reduction in the number of deaths in July 1847, in which a total of 51 people had died of yellow fever: twenty soldiers, 13 individuals in the quartermaster's department, 11 Mexicans, and seven foreigners within a two-week span from May 1 through May 16. This was a significant decline from the earlier US reports of hundred deaths per day in the 1820s and 1830s. Furthermore, by October 1847, the cases of sickness reported, according to the New York Herald were no longer yellow fever but mostly consisted of intermittent fever and scurvy (25 Oct. 1847, p.2). In 1848, US forces defeated Santa Anna and both sides signed the Treaty of Guadalupe Hidalgo, granting the United States a large portion of California, Texas, and other territories that would later be formed into US states and increasing the mobility of Americans into former Mexican territories. Despite this movement, yellow fever would remain a topic of discussion for individuals in the United States as they looked to increase trade with Veracruz.

\section{Final considerations}

Veracruz held a central space of concern given the close proximity and pre-established trade routes with the United States. During the invasions of the Spanish (1823-1825), the French (1832), and the United States (1846-1848), yellow fever worked for and against the Mexican military forces as it crippled the population of foreign soldiers and slowed their advancement into the interior of the country, while also devastating the soldiers coming from the interior of Mexico. While the disease had clear repercussions for US and Mexican soldiers during the Mexican-American war, yellow fever and its significant place in Veracruz had been etched into the US media in the early nineteenth century, especially leading up to the US invasion of Mexico. By the end of the conflict with Mexico, the United States presented themselves as the only ones who could adequately combat yellow fever in Veracruz. In fact, reports of yellow fever in Veracruz had dropped drastically in the immediate years after 1847. Despite a reduction in the discussions of disease in the port city of Veracruz in US newspapers, Veracruz continued to appear in the commerce and trade sections of these periodicals. Perhaps the reduction of yellow fever outbreaks increased confidence in US port cities, which allowed for an expansion of trade possibilities 
between cities on the US littoral and Veracruz. In both trade and war, the tragedy of disease held a constant place in depictions to the masses in the United States. Although the constant emergence of epidemics made Veracruz appear to be a metropolis of pestilence, its position as a central node in local, national, and international trade networks made it a crucial commercial space, demonstrating the problematic relationship between trade and environment in early nineteenth-century Veracruz and the Atlantic world.

The US populous could not ignore that in trade relationships, ports had very little control over what entered and exited along with goods. When yellow fever struck ports like Veracruz, it created an image of Veracruz that would become part of the US imaginary. People from southern and eastern coastal regions in the United States directly linked to trade with Veracruz received constant reminders of the port city and its potential to spread its devastation to US cities. While Veracruz has not experienced a central place in the United States of America's historical narrative, periodicals from the early nineteenth century illustrate a strong relationship between Veracruz and the United States. The varied representations of Veracruz in US newspapers illustrate that it was not only part of the American psyche; it was also tied to the United States in terms of commerce, progress, and health concerns.

Illness, although a major impediment in the trading world, did not mean an end to life in the port city. The medical world of the mid-nineteenth century made advances in medical discoveries. By the late 1840s, the medical establishment in Veracruz had proved that it could handle several cases of illnesses that had previously plagued the port. Early nineteenth-century US periodicals depicted the complexities of the port city of Veracruz from its beautiful streets to the devastation of yellow fever through narratives that informed and captivated audiences. Such a significant position demonstrates how yellow fever in Veracruz was part of an international discussion as well as the ways that Veracruz held a prominent position in the US imaginary through commerce and contamination in the early nineteenth century.

By the end of the nineteenth century, Mexico had entered prominently into the international search for the causes and cures of yellow fever. In fact, the American Association of Public Health created an international committee to find the origin and causes of yellow fever in an effort to wipe out the disease "at its birth," where they collaborated in Mexico in 1892. In reference to Mexico, the Gulf of Mexico was one of the primary spaces of concern for researchers conducting investigations on the causes and attempts at eradicating the disease (Liceaga, 1894). According to Eduardo Liceaga, the German researcher Dr. Carlos Heinemann had conducted several studies in the port city and determined that for roughly two centuries, Veracruz had been the most important focal point of yellow fever in the Gulf coast (for Mexico).

After the Mexican-American War, Veracruz drew more intense attention from the national and international health community as researchers collaborated across linguistic, political, and geographic barriers to address concerns revolving around yellow fever. Physicians and researchers traveled to Veracruz to conduct research on yellow fever. More specifically, doctors like US Army Physician George Miller Sternberg traveled to Mexico to study the causes and potential cures for this aggressive disease with local Mexican doctors 
such as Dr. Carmona y Valle of Mexico City and Daniel Ruiz of Veracruz. Indeed, the concerns around yellow fever in Veracruz remained in the US imaginary, yet its importance in the late nineteenth century is most understandable when taking account of the constant appearance and discussions of Veracruz in the early nineteenth century, especially the immediate post-independence years (1821-1848).

\section{REFERENCES}

ALBANY...

Albany Evening Journal, 17 June 1843.

ALCALÁ FERRÁEZ, Carlos.

Viajeros y enfermedades: una aproximación a la situación epidemiológica en la península de Yucatán entre 1834 y 1847. [S.1.]: Universitat de Barcelona. 2010.

ALVARADO, Ignacio.

La fiebre amarilla en Veracruz: estudios clínicos hechos en el hospital civil de Veracruz. México: Oficina Tipográfica de la Secretaría de Fomento. 1897.

ÁLVAREZ, Cristina Gómez.

Comercio y comerciantes del libro en la Carrera de Indias: Cádiz-Veracruz, 1750-1778. Historia Mexicana, v.57, n.3, p.621-667. 2008.

ARCHER, Christon.

The key to the kingdom: the defense of Veracruz, 1780-1810. The Americas, v. 27, n.4, p.426-449. 1971.

AUGUSTA CHRONICLE.

Augusta Chronicle, 7 June 1847.

AUGUSTA CHRONICLE.

Augusta Chronicle, 16 Apr. 1847.

AUGUSTA CHRONICLE.

Augusta Chronicle, 12 June 1846.

AUVINET, Gabriel; BRIULET, Monique.

El doctor Denis Jourdanet: su vida y su obra.

Gaceta Médica de México, v.140, n.4, p.426-429. 2004.

BALTIMORE...

Baltimore Gazette and Daily Advertiser, 10 Feb. 1830.

BAUER, K. Jack.

The Veracruz Expedition of 1847. Military Affairs, v.20, n.3, p.162-169. 1956.

BELL, Andrew McIlwaine.

Mosquito soldiers: malaria, yellow fever, and the course of the American Civil War. Baton Rouge: Louisiana State University Press. 2010.

BIRN, Anne-Emanuelle.

Marriage of convenience: Rockefeller International Health and revolutionary Mexico. Rochester, NY: Boydell and Brewer. 2006.
BLÁZQUEZ DOMÍNGUEZ, Carmen.

Comerciantes y desarrollo urbano: la ciudad y puerto de Verazcruz en la segunda mitad del siglo XVIII. Tiempos de América, v.4, n.5, p.21-36. 2000 .

BNCE.

Banco Nacional de Comercio Exterior. $E l$ comercio exterior y el artesano mexicano, 18251830. Mexico: BNCE. 1965.

BOSTON...

Boston Commercial Gazette, 30 Oct. 1827.

BOSTON...

Boston Commercial Gazette, 23 Jan. 1823.

BULLOCK, William.

Six months' residence and travels in Mexico; containing remarks on the present state of New Spain, its natural productions, state of society, manufactures, trade, agriculture, and antiquities, etc. Port Washington, NY: Kennikat Press. 1971.

CHABERT, Juan Luis; LICEAGA, Casimiro. Reflecsiones medicas y observaciones sobre la fiebre amarilla: hechas en Veracruz de órden del Supremo Gobierno de la Federacion Mexicana, y redactadas en francés. Mexico: Imprenta del Supremo Gobierno, en Palacio. 1828.

CHICO, Rachel Anne.

Route to the capital, route to the sea: domestic travel, regional identity and local isolation in the Veracruz-Mexico City corridor, 1812-1876. Berkeley: University of California Press. 2006.

CODINACH, Guadalupe Jiménez.

Veracruz, almacén de plata en el Atlántico: la Casa Gordon y Murphy, 1805-1824. Historia Mexicana, v.38, n.2, p.325-353. 1988.

COMMERCIAL ADVERTISER. Commercial Advertiser, 27 Dec. 1843.

CRUZ VELÁZQUEZ, Romeo.

Los hospitales del puerto de Veracruz, 1760-1800.

Veracruz: Instituto Veracruzano de Cultura. 1998.

CUENYA, Miguel Angel; ESTRADA URROZ, Rosalina.

Enfermedad, epidemias, higiene y control social: nuevas miradas desde América Latina y México. 
Puebla: Benemérita Universidad Autónoma de Puebla; Instituto de Ciencias Sociales y Humanidades; Dirección de Fomento Editorial. 2013.

\section{CUSTOMS INCOME.}

Customs income. Benson Latin American Collection; Mariano Riva Palacio Collection, 1716-1880. 1845-1635-UTBL-Mariano Riva Palacio Collection (General Libraries, University of Texas at Austin). n.d.

DAILY GEORGIAN.

Daily Georgian, 5 Aug. 1828.

DAILY UNION.

Daily Union, 7 Apr. 1847.

DELGADO, Ana Laura.

Cien viajeros en Veracruz: crónicas y relatos. t.2: 1755-1816. Veracruz: Gobierno del Estado de Veracruz. 1992.

EASTON STAR.

Easton Star, 13 Apr. 1847.

EL CENSOR.

El Censor, 31 July 1839.

EL CENSOR.

El Censor, 29 Aug. 1833.

EVENING POST.

Evening Post, 29 Apr. 1847.

EVENING POST.

Evening Post, 15 May 1841.

EVENING POST.

Evening Post, 21 Feb. 1823.

FOOS, Paul.

A short, offhand, killing affair: soldiers and social conflict during the Mexican-American War. Chapel Hill: University of North Carolina Press. 2002.

GARCÍA DÍAZ, Bernardo.

The State of Veracruz. Veracruz: Veracruz State Government. 1994.

GARCÍA DÍAZ, Bernardo; GUERRA, Sergio. La Habana/Veracruz, Veracruz/La Habana: las dos orillas. Veracruz: Universidad Veracruzana. 2002.

GARCIA SANCHO, Juan de.

Carta a Jose de la Camara. Benson Latin American Collection; Mariano Riva Palacio Collection, 1716-1880. 1845-1747-UTBL-Mariano Riva Palacio Collection (General Libraries, University of Texas at Austin). 15 May 1845.

JUÁREZ MARTÍNEZ, Abel.

Las ferias de Xalapa y otros ensayos. Veracruz: Instituto Veracruzano de Cultura. 1995.
KNAUT, Andrew L.

Yellow fever and the late colonial public health response in the port of Veracruz. The Hispanic American Historical Review, v.77, n.4, p.619-644. 1997.

LICEAGA, Eduardo.

Contribución al estudio de la fiebre amarilla bajo el punto de vista de su geografía médica y su profilaxia, en la República Mexicana: memoria presentada al Comité de la Fiebre Amarilla de la Asociación Americana de Salubridad Pública. México: Oficina Tipográfica de la Secretaria de Fomento. 1894.

LODOLA, Soraya; GOIS JUNIOR, Edivaldo. Theories about the propagation of yellow fever: the scientific debate in the São Paulo press between 1895 and 1903. História, Ciências, Saúde - Manguinhos, v.22, n.3, p.687-704. 2015.

LOZANO-FUENTES, Saul et al.

The dengue virus mosquito vector Aedes aegypti at high elevation in México. The American

Journal of Tropical Medicine and Hygiene, v.87, n.5, p.902-909. 2012.

LUCENA SALMORAL, Manuel.

El Comercio del Caribe con España a comienzos del siglo XIX: los terminales de La Guaira, Veracruz, La Habana, Portobelo-Panamá y de los puertos norteamericanos. Caracas: Universidad de Alcalá de Henares; Universidad de Murcia. 1983.

MAROÑO, María Luisa González.

Salud pública en el puerto de Veracruz a principios del siglo XIX. Ulúa, v.0, n.3. 2015.

MASSACHUSETTS SPY.

Massachusetts Spy, 12 Aug. 1846.

MASSACHUSETTS SPY.

Massachusetts Spy, 6 Aug. 1828.

MILWAUKEE SENTINEL.

Milwaukee Sentinel, 14 May 1847.

NEWBURYPORT HERALD.

Newburyport Herald, 7 Aug. 1846.

NEWPORT MERCURY.

Newport Mercury, 13 July 1833.

NEW YORK HERALD.

New York Herald, 25 Oct. 1847.

NEW YORK HERALD.

New York Herald, 12 July 1847.

OCHOA CONTRERAS, Octavio; VELÁSQUEZ ORTÍZ, Flora.

Volumen, dinámica y estructura de la población total del Estado de Veracruz, 1793-1980. Xalapa: Instituto de Investigaciones y Estudios Superiores Económicos y Sociales; Universidad Veracruzana. 1986. 
PEDRERA, Federico.

Certificados relativos al tratamiento de la fiebre amarilla por el específico del Dr. Pedrera en el puerto de Veracruz. México: Imprenta de la Secretaria de Fomento. 1883.

PHILADELPHIA INQUIRER.

Philadelphia Inquirer, 17 June 1843.

RHODE-ISLAND AMERICAN...

Rhode-Island American and General Advertiser, 28 Jan. 1823.

RHODE-ISLAND REPUBLICAN.

Rhode-Island Republican, 29 June 1826.

RIO, Narciso del.

Yellow-fever in Veracruz. Public Health Papers and Reports, v.18, p.292-295. 1892.

RONZÓN, Jose.

El panorama epidémico en el Golfo de Mexico: los puertos de La Habana, Veracruz y New Orleans en la segunda mitad del siglo XIX. Papeles de Población, n.16, p.167-184. 1998.

ROSENAU, Milton Josephet al.

Experimental studies in yellow fever and malaria at Vera Cruz, Mexico. Washington: GPO. 1905.

SAUNIER, J.B.

Investigaciones sobre la fiebre amarilla ó vómito de Veracruz: sus modos curativos y profilacticos al uso de los médicos y al alcance del pueblo. Puebla: Osorio. 1866.

SIEMENS, Alfred H.

Between the summit and the sea: Central

Veracruz in the nineteenth century. Vancouver: University of British Columbia Press. 1990.

SOUTHERN PATRIOT.

Southern Patriot, 8 May 1842.
SOUTHWORTH, John Reginald.

El Estado de Veracruz-Llave: Su historia, agricultura, comercio e industrias, en inglés y español. Liverpool: Blake and Mackenzie. 1900.

SPECTATOR.

Spectator, 3 June 1843.

STERNBERG, George Miller; UNITED STATES; MARINE HOSPITAL SERVICE.

Report on the etiology and prevention of yellow fever. Washington: GPO. 1890.

SUN.

Sun, 28 June 1847.

SUN.

Sun, 28 May 1842.

TRI-WEEKLY...

Tri-Weekly Ohio Statesman, 27 July 1846.

TROWBRIDGE, Silas Thompson.

Observations on yellow fever in Veracruz. Veracruz: C. Trowbridge. 1883.

VARELA, G.

Inoculaciones al hombre con fiebre amarilla, realizadas en Veracruz, al principio de este siglo. Revista de la Asociación Médica Mexicana, v.32, n.647, p.106-108. 1952.

VIESCA TREVIÑO, Carlos. Epidemias y enfermedades en tiempos de la independencia. Revista Médica del Instituto Mexicano del Seguro Social, v.48, n.1, p.47-54. 2010.

WOOD, Andrew Grant.

Revolution in the street: women, workers, and urban protest in Veracruz, 1870-1927. Wilmington, DE: SR Books. 2001. 